\title{
ДИТЯЧА ПРАЦЯ В УКРАЇНІ: ДЕТЕРМІНАНТИ, ХАРАКТЕРИСТИКИ, МІНІМІЗАЦІЯ СОЦІАЛЬНИХ РИЗИКІВ
}

\author{
ДЕТСКИЙ ТРУД В УКРАИНЕ: ДЕТЕРМИНАНТЫ, ХАРАКТЕРИСТИКИ, \\ МИНИМИЗАЦИЯ СОЦИАЛЬНЫХ РИСКОВ
}

\section{CHILD LABOUR IN UKRAINE: DETERMINANTS, DESCRIPTIONS, AND SOCIAL RISK'S MINIMIZATION}

\begin{abstract}
Викорінення дитячої праці $i$ запобігання ї̈ поширенню $\epsilon$ важко досяжними благочестивими иілями міжнародного співтовариства. В боротьбі проти економічної експлуатації дітей береться до уваги не лише забезпечення їхніх прав, але й умови формування їхнього майбутнього добробуту. При иьому найбільшими факторами ризику його руйнування виступають слабке здоров'я прачюючих дітей та неповне відвідування ними школи. Дитяча праця в Украӥні має начіональну специфіку, всебічне вивчення якої $є$ необхідним для формування і впровадження ефективної політики у цій сфері. Вивчення статистичних баз відповідних досліджень є необхідним для розуміння характеристик дитячої пращі в Украӥні і підвищення суспільної поінформованості щуодо ї̈ негативних наслідків. Здійснюючи опис головних особливостей дитячої праџі в Украӥні, автор надає відомості, необхідні для розробки державної політики у иій сфері і визначає найбільш актуальні сочіальні загрози, викликані наявністю дитячої прачі в Украӥні. В публікаціі також представлено перспективні шляхи для викорінення дитячої прачі та запобігання ї̈ поширенню.
\end{abstract}

Ключові слова: дитяча праця, соціальні ризики, загрози, економічна експлуатація дітей, умови роботи, заходи, політика.

Искоренение детского труда и предотвращчение его распространения являются труднодостижимыми благочестивыми иелями международного сообщества. В борьбе против экономической эксплуатачии детей принимается во внимание не только обеспечение их прав, но и условия формированияих будущего благополучия. При этом наибольшими факторами для риска его нарушения выступают ослабленное здоровье работающих детей и неполное посещение ими икольь. Детский труд в Украине имеет национальную специфику, всестороннее изучение которой является необходимым для формирования и внедрения эффективной политики в данной сфере. Изучение статистических баз соответствующих исследований является необходимым для понимания характеристик детского труда в Украине и повышения общественной информированности на предмет его негативных последствий. Осуществляя описание главных особенностей детского труда в Украине, автор предоставляет информачию, необходимую для разработки государственной политики в этой сфере, и определяет наиболее актуальные социальные угрозы, вызванные присутствием детского труда в Украине. В публикации также представлены перспективные пути для искоренения детского труда и предотвращения его распространения. 
Ключевые слова: детский труд, социальные риски, угрозы, экономическая эксплуатация детей, условия труда, меры, политика.

The elimination and prevention of child labour are hard-hitting and devout goals of international community. Not only observance of children's rights, but their future welfare is taken into account in the struggle against economic exploitation of children. The main factors of risk for them are bad health and poor school attendance. Child labour in Ukraine has its national specific, which require comprehensive analysis for the forming and implementation of effective policies in the area. The studies of statistical data of appropriate surveys on the issue are important for understanding of the descriptions of child labour in Ukraine and raising the awareness of its negative consequences. Bydescribbing main characteristics of child labour in Ukraine the author gives the necessary information for the policy design and defines the most dangerous social threats, provoked by child labour. The publication also offers promising ways to the prevention and elimination of child labour.

Key words: child labour, social risks, threats, economic exploitation of children, conditions of work, measures, policies.

Вступ. Дитяча праця є специфічним соціально-економічним явищем, викликаним дією різноманітних чинників, що передусім залежать від рівня економічного розвитку країни, в якій проживає дитина, обсягу державного забезпечення освіти дітей, соціально-культурних поглядів на роль дитини в суспільстві. Якщо в окремих розвинених країнах залученість дітей до формальної і неформальної оплачуваної роботи має навчально-виховний характер, то в країнах, що розвиваються, головним мотивом використання праці дітей $є$ бідність і обмеженість освітніх можливостей для підростаючого покоління. Саме у випадках, коли дитяча праця має вимушений характер, вона схильна набувати своїх найгірших форм, внаслідок чого наносить шкоду фізичному, психічному, розумовому і моральному розвитку дітей. Стратегії (як глобальні, так і національні), спрямовані на викорінення останнього виду дитячої праці, розробляються і реалізовуються за участю і сприяння Дитячого фонду Організації Об'єднаних націй (ЮНІСЕФ), Міжнародної організації праці (МОП), Всесвітнього банку, ряду правозахисних організації та груп.

В нашій країні дитяча праця має власну специфіку, що складається під дією наступних факторів:

збереження давньої традиції використання дитячої праці (як однієї 3 форм ручної некваліфікованої праці) в сільському господарстві, яке все ще відіграє помітну економічну роль в господарському житті країни;

- домінування культурних установок щодо корисного виховного характеру праці (в тому числі безоплатної, т.з. «суспільно корисної») для розвитку особистості, що склалися ще в радянський період;

- зниження доступності якісної освіти для дітей і послаблення державного контролю за відвідуванням дітьми навчальних закладів та рівнем їх успішності; 
- скорочення можливостей для організації доступного дитячого дозвілля у позашкільний час;

- поширення дитячої безпритульності;

- збереження кризових явищ в економіці, зниження рівня життя i поширення бідності;

- послаблення державного контролю за дотриманням трудового законодавства і соціальних прав (в тому числі трудових) неповнолітніх.

Внаслідок складної дії зазначених чинників дитяча праця в Україні набула характеристик, притаманних останній як в розвинених і заможних, так i в економічно відсталих країнах 3 високими рівнями бідності населення. Фактичне дотримання особливих трудових прав неповнолітніх, якими наділяє їх держава, має поодинокий характер. Головною перешкодою для здійснення державного контролю за дотриманням прав неповнолітніх працівників $є$ їхня переважна участь у неформальних видах зайнятості.

В останніх дослідженнях в галузі дитячої праці спеціалісти неодноразово наголошували, що прогалини в діючих законодавчих нормах не дозволяють притягнути до відповідальності ні осіб, винних у порушеннях окремих трудових прав неповнолітніх, ні осіб, основним джерелом прибутків яких є економічна експлуатація дітей [1 - 3].

Про поширення найгірших форм дитячої праці в Україні наголошувалося у спеціальних доповідях провідних наукових установ [4] та, неодноразово, на найвищому державному рівні у доповідях Уповноваженого Верховної Ради України 3 прав людини [5 - 6]. Не зважаючи на те, що Україною ратифіковано Конвенцію ООН про права дитини, Конвенцію МОП №138 про мінімальний вік прийому на роботу та Конвенцію МОП №182 про найгірші форми дитячої праці (з внесенням відповідних змін до національно законодавства), систематичність порушень соціально-трудових прав неповнолітніх обумовлює виникнення як актуальних, так і перспективних загроз соціальній та трудоресурсній безпеці України.

При цьому успішність реалізації стратегії викорінення найгірших форм застосування дитячої праці передусім залежить від ретельного вивчення іï особливостей i домінуючих характеристик, що i обумовило актуальність даного дослідження.

Постановка завдання. Метою дослідження $\epsilon$ розробка політичних заходів, спрямованих на мінімізацію соціальних загроз, викликаних дитячою працею в Україні. Для досягнення цієї мети було виконано низку завдань: виділено детермінанти дитячої праці; здійснено оцінку особливостей формування та масштабів поширення ㄲi негативних характеристик; визначено загрози трудоресурсній і соціальній безпеці, які вони несуть; встановлено перспективні напрями мінімізації цих загроз. 
Методологія. Дослідження виконано 3 застосуванням методів логічного, соціологічного і статистичного аналізу, синтезу, методу аналогії і порівняння, узагальнення, діалектичного методу, демостатистичних методів абсолютних, відносних і середніх величин, методу експертних оцінок.

Під час написання статті інформаційною базою послужили статистичні та соціологічні результати дослідження Дитячої праці в Україні (здійсненого на замовлення МОП з метою реалізації Міжнародної програми з викорінення найгірших форм дитячої праці МОП-ІПЕК),яке складалося 3 двох частин: модульного опитування домогосподарств, проведеного з жовтня по грудень 2014 р. Державною службою статистики в межах дослідження економічної активності населення; опитування дітей, які перебували на вулиці, здійсненого центром «Соціальний моніторинг» в лютому-березні 2015 p.

Результати дослідження. Під час проведення обстеження в Україні працювало 607,4 тис. дітей, кожна десята $(10,3 \%)$ в країні дівчинка і більше, ніж кожен десятий $(12,9 \%)$ хлопчик.

Результати дослідження свідчать про те, що рівень залученості дітей до праці передусім залежить типу місцевості, в якій вони проживають, регіону, соціально-економічного статусу батьків.

Найбільш значущими виглядають відмінності у характеристиках дитячої праці, що випливають 3 iї аналізу в міжпоселенському розрізі. На момент проведення обстеження до оплачуваної зайнятості було залучено 142,2 тис. міських та 465,2 тис. сільських дітей, т.б. 4\% та $24 \%$ дитячого населення у віці 5 - 17 років відповідно (розраховано на основі даних Держстату про кількість дітей відповідного віку в цих видах поселень). Отже, в той час як в сільській місцевості працювала майже кожна четверта дитина, в міських поселеннях в оплачуваній зайнятості брала участь менше ніж кожна двадцята. В сільській місцевості частіше за все до праці були залучені діти 12 - 14 та 15 - 17 років (були зайняті 38,4\% та 39,8\% з них відповідно), в міських поселеннях - діти 12 - 14 років (з них працювали $11,5 \%$, в той час як серед 15 - 17-річних таких було 5,9\%).

Частіше за все до праці залучали дітей в Західній Україні (там на обстежуваному тижні працювали $18,3 \%$ дітей), рідше за все - на Сході (7\% дітей).

Майже кожна третя працююча під час обстеження дитина $(30,8 \%)$ була 3 неповної сім'ї, в містах - майже кожна друга (46,2\% проти $25,2 \%$ таких у сільській місцевості). Одним 3 провідних факторів залучення дітей до оплачуваної зайнятості виступав рівень освіти їхніх батьків, що визначає ризик виникнення бідності, особливо у домогосподарствах з дітьми. Так, більше ніж дві третини $(78,2 \%)$ працюючих дітей мали батька, який не отримав вищої освіти, $63,8 \%$ - матір з середнім рівнем освіти.

Причини роботи та спрямування отриманих коштів 
Головним мотивом зайнятості більшість (80,1\% опитаних) дітей назвали бажання надати допомогу батькам. Незважаючи на те, що в сільській місцевості проживає менше дітей, допомогу батькам вони надають значно частіше - на обстежуваному тижні $з$ цієї причини працювали 387,6 тис. сільських та 98,7 тис. міських дітей. Крім того, близько 2,8 тис. дітей надавали таку допомогу не на добровільній основі - їх змусили працювати батьки або опікуни. Абсолютна більшість (2,2 тис.) з них були дітьми з наймолодшої вікової групи 5 - 11 років, дівчатками (2 тис.), міськими жителями (2 тис.). Помітна частка дітей працювали з економічних причин: вони або бажали мати власні кошти або ж трудилися для забезпечення додаткового доходу сім'ї.

Робота, яку в нашій країні під час обстеження виконували діти замість батьків, опікунів або інших родичів, майже повністю була на плечах хлопців (3 5,3 тис. працюючих 3 цієї причини дітей 5,1 тис. були хлопцями). Переважна більшість таких дітей (4,7 тис.) була з сільської місцевості.

\section{Сфери і місия прикладання дитячої пращі}

Абсолютна більшість працюючих в Україні дітей $(93,3 \%)$ були зайняті у сільському господарстві. Серед інших видів економічної діяльності, до яких були залучені діти, можна відзначити оптову та роздрібну торгівлю $(2,2 \%$ зайнятих дітей), професійну, наукову та технічну діяльність $(0,9 \%)$ та діяльність домашніх господарств (1\%).

Окрему картину дитячої зайнятості складає робота дітей, які під час виконання своїх трудових обов'язків часто вимушені перебувати на вулиці. Найбільш розповсюдженими видам зайнятості дітей, які працювали на вулиці, під час проведення дослідження були: прохання милостині (цим займалися $12 \%$ опитаних дітей), виконання сільськогосподарських робіт $(11,7 \%)$, робота кур'єром, розповсюджувачем преси (працювали 10,3\%), зайнятість у торгівлі (було охоплено 9,5\% опитаних дітей), надання сексуальних послуг (займалися $9 \%)$, здача вторинної сировини $(8,2 \%)$.

Вид зайнятості, до якої були залучені діти 3 цього соціального прошарку, напряму залежав від їхньої статі. При цьому діти обох статей частіше за все були залучені до принижуючих гідність видів зайнятості. Так, до надання сексуальних послуг були залучені переважно дівчата, і займалася цим більше ніж кожна п'ята 3 них (21,5\% проти 0,4\% хлопців). Абсолютна більшість цих дітей (94\%) була представниками вікової групи 15 - 17 років. В містах частота залучення до цього виду заробітку була вдвічі більшою, ніж у сільських поселеннях (було зайнято 9,4\% опитаних дітей та 4,9\% опитаних дітей відповідно). Хлопчики частіше за все були зайняті проханням милостині (13,9\% від усіх опитаних дітей цієї статі, які працювали на вулиці), виконанням сільськогосподарських робіт (13,4\%), роботою кур'єром або розповсюджувачем (13\%). Цілком зрозуміло, що до прохання милостині частіше за все були залучені наймолодші дітки, 5 - 11 років. До цієї вікової 
групи належали 81,3\% від усіх дітей, які цим займалися, і 37,5\% працюючих на вулиці дітей цього віку. Жебракували діти виключно в містах, не залежно від їхнього віку.

Серед дівчат іншими популярними видами зайнятості були торгівля (16,1\% працюючих дівчат), робота офіціанткою (12,3\%), робота танцівницею у нічному клубі та зайнятість у сільському господарстві (по 9,8\%), прохання милостині $(9,2 \%)$. Хлопці частіше були залучені до сільськогосподарських робіт $(13,4 \%)$, роботи кур'єром або розповсюджувачем (13\%), роботи вантажником $(12,2 \%)$ або різноробочим $(10,9 \%)$, до здачі вторинної сировини $(10,5 \%)$.

\section{Визначальні чинники оплати дитячої прачуі і ї̈ розмір}

Середній заробіток дітей, які працювали на обстежуваному тижні, обумовлювався їх віком, місцем проживання і найбільше - видом економічної діяльності, до якої вони були залучені. Найвищу заробітну плату (в середньому 740 грн. на місяць) отримували підлітки $15-17$ років, найменшу (104 грн.) - діти у віці 5 - 11 років. Діти з міст отримували вдвічі більшу зарплату, ніж жителі сільської місцевості (691 грн. та 340 грн. відповідно). Що стосується сфери зайнятості, то найвищими були рівні оплати праці в будівництві (в середньому 1608 грн. на місяць), в галузі тимчасового розміщення та організації харчування (1500 грн.), у сфері професійної, наукової та технічної діяльності (1392 грн.).

Природно, що середній заробіток працюючих дітей зростає 3 підвищенням їх віку. Це пов'язано як зі збільшенням кількості відпрацьованого часу, так і з підвищенням здатності освоювати складні професійні навички. Особливо вагомим це зростання було в сільському господарстві. Якщо середньомісячна заробітна плата дітей віком 5 - 11 років там дорівнювала 82,8 грн. на місяць, то у наступній віковій групі $(12-14$ років) вона була вже 214,5 грн., у найстарших дітей $(15-17$ років $)-457,8$ грн.

\section{Інтенсивність дитячої праиі}

Дитяча праця в Україні характеризується середньою інтенсивністю. Так, абсолютна більшість дітей, які працювали на обстежуваному тижні, були зайняті оплачуваною працею від 1 до 13 годин (46,2\% 3 них $1-6$ годин і $38,9 \%-7-13$ годин). Кількість відпрацьованих на тиждень годин очікувано збільшується з віком. Так, $63,1 \%$ діток $5-11$ років були зайняті 1 - 6 годин на тиждень і менше ніж кожен третій з них $(29,5 \%)-7-13$ годин. У наступній віковій групі відбувається помітний перерозподіл часток зайнятий в цих робочих режимах дітей: в першому працювали трохи менше половини 3 них $(49,4 \%)$, в другому - понад кожен третій $(38,4 \%)$. Поряд 3 цим, майже вдвічі більше дітей 12 - 14 років ( $11,7 \%$ проти $6,6 \%$ молодших робітників) працювали 14 - 24 годин на тиждень. У найстаршій же віковій групі вже найбільша частка дітей $(46,9 \%)$ працювала 7 - 13 годин на тиждень. 
Частка дітей, робоче навантаження яких перевищувало гранично допустимі для їхнього віку норми, була хоча й статистично значимою, проте невисокою. Так, 12,2\% дітей віком 12 - 14 років працювали понад 14 годин на тиждень, 2,2\% дітей 15 - 16 років працювали 25 або більше годин на тиждень. Ще $8,3 \%$ дітей віком 17 років працювали 35 і більше годин на тиждень.

Особливості зайнятості представників соиіально вразливих груп

Однією з негативних особливостей зайнятості дітей, які працювали на вулиці, і були там опитані щодо найбільш вразливих аспектів їхньої зайнятості, була наявність помітного конфлікту між роботою і навчанням. Так, більше ніж кожен четвертий 3 них $(28,6 \%)$ повідомив, що пішов працювати через небажання продовжувати освіту (серед дівчат майже кожна третя - 30,9\%). Значна частка дітей працювали через те, що не бачили сенсу у навчанні або не вступили до вищих і спеціалізованих середніх навчальних закладів (8,7\% та 7,9\% відповідно).

На жаль, форма договору про працевлаштування, за якою працювали опитані діти, допускала порушення або обмеження їхніх прав. Більше ніж 93 10 дітей працювали або за усною домовленістю з роботодавцем або взагалі без неї (63,3\% та 33,4\% відповідно). Вчасні виплати отримували тільки 37,9\% 3 них, більше, ніж кожен п'ятий $(20,4 \%)$ мав виплати, значно менші за домовлені, 17\% стикнулися зі значними затримками виплат.

Зважаючи на ці обставини, діти нерідко трудилися, маючи умови праці, що не відповідають встановленим законом санітарно-гігієнічним нормам. Найбільш поширеними 3 них були холод i протяги (були присутні на робочому місці у 40,4\% дітей), шум (у 39,9\%) і запиленість (у 31,4\%). Крім того, майже кожна четверта дитина $(24,7 \%)$ виконувала тяжку фізичну роботу, більше, ніж кожна п'ята $(21,2 \%)$ повідомила, що на робочому місці їй не дозволялось відволікатись, майже кожна п'ята працювала в умовах підвищеної загазованості. Значна частка дітей відчувала на собі дію таких несприятливих для роботи чинників, як неприємний запах $(14,7 \%)$ та велика нервова напруга (14\%).

Висновки. Опис визначальних характеристик дитячої праці, приведений у статті, дозволяє встановити дуалістичний характер зайнятості неповнолітніх. Перш за все, зайнятість переважної кількості дітей стимулюється та регулюється їхніми батьками, опікунами та особами, які їх заміщують. В цьому випадку іiі вимушений характер (продиктований недостатнім рівнем матеріальної забезпеченості сімей) не наносить значної шкоди здоров'ю і фізичному розвитку дітей, не вступає в конфлікт з їхніми освітніми перспективами. Водночас помітна частка дітей працює на вулиці в умовах, що не відповідають санітарно-гігієнічним нормам. Нерідко їхні роботодавці $\epsilon$ порушниками не лише трудового, але й кримінального законодавства. В такому разі трудова діяльність дітей не просто наносить 
шкоду їхньому власному фізичному, психічному, розумовому і моральному розвитку, але й носить суспільно небезпечний характер. Саме ця категорія працюючих дітей повинна стати головним об'єктом державної політики регулювання зайнятості неповнолітніх.

Наукова новизна отриманих результатів полягає у розвитку теоретикометодичних засад дослідження дитячої праці та розробленні практичних рекомендацій щодо мінімізації соціальних загроз, викликаних ії негативними характеристиками.

Отримані результати мають практичне значення для створення цілісної системи протидії економічній експлуатації дітей, що включає в себе заходи попередження і профілактики, заходи прямого втручання та реабілітаційноінтеграційні дії. Теоретичними результатами дослідження $\epsilon$ розвиток теоретико-методологічних підходів до дослідження дитячої праці, що, на відміну від існуючих, розглядають це явище крізь призму забезпечення соціальної і трудоресурсної безпеки.

Отже, до попереджувальних заходів відносяться:

1. Реалізація просвітницьких програм, спрямованих як на попередження населення (в тому числі батьків та осіб, які їх заміщують) про кримінальну відповідальність за дії, спрямовані на втягнення дітей найгірших форм дитячої праці, так і на підвищення поінформованості неповнолітніх щодо їхніх трудових прав та довгострокових наслідків раннього масштабного залучення до дитячої праці та роботи в умовах, що не відповідають санітарногігієнічним нормам і законодавству в питаннях охорони праці.

2. Підвищення якості організації дозвілля дітей та забезпечення їх соціальної включеності (збільшення переліку виховних, спортивних i конкурсних заходів, що проводяться в загальноосвітніх закладах; розширення функцій учнівського самоврядування; організація волонтерської діяльності дітей;збільшення доступності закладів позашкільного виховання та спортивно-оздоровчих секцій).

3. Удосконалення методів профілактичної роботи 3 дітьми, схильними до девіантної поведінки і проведення індивідуальної профілактики серед них шкільними психологами, соціальними робітниками, представниками органів правопорядку.

До заходів прямої та безпосередньої протидії відносяться:

1. Внесення змін до національного законодавства, спрямованих на посилення юридичної відповідальності осіб, які займаються залученням дітей до найгірш форм дитячої праці.

2. Усунення правових та організаційних перепон для здійснення ефективного прокурорського нагляду за дотриманням трудових прав неповнолітніх. 
3. Посилення відповідальності роботодавців за залучення дітей до неформальних форм зайнятості 3 метою розширення трудових прав неповнолітніх на всіх працюючих дітей.

До заходів психологічної реабілітації та підвищення соціальної включеності відносяться:

1. Проведення психологами, медичними працівниками і соціальними педагогами оцінки реальної і потенційної шкоди фізичному, моральному i психологічному розвитку дітей, спричиненої залученням дітей, які підлягають реабілітації, до найгірших форм дитячої праці. Вироблення індивідуального плану корекції відхилень у розвитку для кожної дитини.

2. Проведення серед таких дітей роз'яснювальної роботи щодо підвищеного ризику для них в подальшому бути залученими до злочинної та антигромадської діяльності.

3. Надання соціальними працівниками дітям, які були залучені до найгірших форм зайнятості, допомоги у адаптації до нових умов життя.

4. Ознайомленні таких дітей з механізмом захисту своїх соціальних i трудових прав, забезпечення їм постійного діючого каналу зворотного зв'язку та джерела отримання консультативної допомоги.

5. Забезпечення дітям з груп ризику можливостей залучення до легальної оплачуваної зайнятості за наявності необхідності покращення їх матеріального становища.

Зазначені дії здатні не лише знизити рівень залучення дітей до найгірших форм дитячої праці, але й спрямовані на зниження загальних ризиків їх соціальної дезадаптації, обмеження масштабів маргіналізації окремих категорій зайнятих серед молоді, підвищення правової i громадянської грамотності в середовищі дітей і підлітків, формування якісно нової культури трудових відносин. В цьому контексті подальші наукові розробки повинні бути спрямовані на конкретизацію зазначених вище заходів і опис результатів втілення пілотних програм.

\section{Література:}

1. Васильківська І.П. Використання дитячої праці: кримінально-правовий аспект / I. П. Васильківська// Вісник Академії адвокатури України. - 2012. - Число 3 (25). - С. 168 - 171. 2. Гладкова $€$. О. Заходи протидії органів внутрішніх справ України втягненню дітей до незаконної дитячої праці, у злочинну та іншу антигромадську діяльність / Є. О. Гладкова // Форум права. - 2014. - № 1. - C. 97-101. - Режим доступу: http://nbuv.gov.ua/jpdf/FP_index.htm_2014_1_19.pdf.

3. Побережний В. Л. Правові засади протидії злочинам, пов'язаним із трудовою експлуатацією дитини / В. Л. Побережний // Юридичний часопис Національної академії внутрішніх справ . - 2014. - № 2. - С. 164 - 173. - Режим доступу: http://nbuv.gov.ua/jpdf/aymvs_2014_2_19.pdf.

4. Праця дітейв Україні: Тематичнадержавна доповідь про становище дітей в Україні (за підсумками 2000 року). - К.: УІСД,2001. - 127 с. 
5. Стан дотримання та захисту правдитини в Україні: Спеціальна доповідь Уповноваженого Верховної Ради України з правлюдини. - К., 2010. - 228 с.

6. Стан дотримання та захисту прав i свобод людини в Україні: Доповідь Уповноваженого Верховної Ради України з прав людини [Електронний ресурс]. - Режим доступу: http://www.ombudsman.gov.ua/images/stories/07022011/Dopovid_5.pdf 